\title{
Seaports and Economic Growth: Panel Data Analysis of EU Port Regions
}

\author{
Gorana Mudronja ${ }^{1, * \mathbb{D}}$, Alen Jugović ${ }^{1} \mathbb{D}$ and Dunja Škalamera-Alilović ${ }^{2}$ \\ 1 Department of Maritime Logistics and Management, Faculty of Maritime Studies, University of Rijeka, \\ Studentska Ulica 2, 51000 Rijeka, Croatia; ajugovic@pfri.hr \\ 2 Department of Economic Theory, Faculty of Economics and Business, University of Rijeka, \\ Ivana FIlipovića 4, 51000 Rijeka, Croatia; dunja.skalamera-alilovic@efri.hr \\ * Correspondence: mudronja@pfri.hr
}

Received: 12 November 2020; Accepted: 9 December 2020; Published: 12 December 2020

\begin{abstract}
Seaports are an important factor in regional economies since their operations create positive effects on the economy. The application of new technologies and innovations is important for the successful operation of seaports; their use reduces costs, facilitates business, increases transparency, and attracts new business entities. This paper analyses the impact of seaports on the growth of regional economies within the endogenous growth theory based on research and development (R\&D) for a sample of 107 European Union's (EU) port regions observed over the period from 2005 to 2015. The model was tested by using the two-step generalized method of moments. The results of the research indicate that seaports have a significant impact on the economic growth of the EU port regions, yet it is necessary to consider other factors that affect the growth of regional economies such as investments in $R \& D$ and human capital. These factors are often underestimated in relation to investment in transport infrastructure; therefore, the guidelines for partial diversion of funds might follow such a path.
\end{abstract}

Keywords: seaports; EU port regions; regional economies; panel data analysis; endogenous growth theory

\section{Introduction}

Seaports are an important factor in domestic and international trade since they are the starting and the ending point of any transport of goods or passengers by sea. They serve as a vital link in many supply chains and distribution channels related to the international trade, thus playing an important role in economic development. Together with their port region, seaports are logistics centers that facilitate the functioning of the global market [1].

The benefits that seaports bring for their economies were widely researched in literature and include reducing transport costs [2,3] and increasing accessibility which directly reduces production factor costs [4,5], increases private investment, encourages trade [6], increases labor productivity and improves educational outcomes [7]. Furthermore, studies concluded that seaports increase employment [8,9] and improve logistics [10] as well as attracting other port-related activities $[9,11]$.

The economic impact of seaports has been researched in the literature from various perspectives, yet there are only a few researches applying theoretical frameworks. In this paper the impact of seaports on their corresponding port regions is researched using endogenous growth theory as a theoretical framework. The theory was first established by Paul Romer [12]; moreover, it considers human capital as the primary source of economic growth, as well as the development of new ideas $[13,14]$.

Building on the above, since seaports operate in highly competitive markets, they require continuous development through innovation and human capital, in order to improve the quality of 
their services and increase the performance of the entire port system. Competition among international seaports is a common occurrence because customers can easily transfer their business to another port, in case they are not satisfied with the business in an existing port. This encourages additional excellence and improved quality of services. It is no longer enough to just transport freight in the most efficient way, yet the market expects seaports to be sophisticated in handling data and ready to implement new technologies.

The aim of this paper is to propose a model based on endogenous growth theory that will assess the impact of seaport operations on the associated regional economy. This will provide a better understanding of the importance of seaports, as well as the importance of human capital and investment in research and development $(\mathrm{R} \& \mathrm{D})$ for the regional economy. The rest of the paper is organized as follows: Section 2 gives literature review, Section 3 describes used materials and methods, Section 4 provides research results, Section 5 discusses results and Section 6 gives concluding remarks.

\section{Literature Review}

Ports are an important participant in international trade and can be considered as the economic infrastructure; therefore, it is assumed that the development of the port will create economic benefits [6]. The port, as an economic entity, has been described by many authors $[1,6,15]$ as a focal point of regional growth that encourages the development of transport and facilitates the progress of international trade. Furthermore, seaports can create new employment opportunities through the effects associated with their operations and logistics activities (warehousing, distribution, containerization etc.). The contribution of seaports to economic growth is significant due to their added value and logistics activities that take place in their vicinity. They attract new industries and create the preconditions for the development of other economic activities near ports [16]. The impact of seaports on the economy has been researched from various aspects such as the impact on the regional economy and impact on the economy of the city.

Park and Seo [15] researched the economic impacts of seaports on regions in Korea by using the augmented Solow model. Empirical findings show that freight ports without sufficient freight traffic impede regional economic growth. On the other hand, if ports have sufficient freight traffic, they contribute to regional economic growth. The results also show that container port activities have a positive impact on regional economic growth, while investments in the port indirectly lead to economic growth. Bottasso et al. [6] researched the connection between seaports and regional gross domestic product (GDP). The research results indicate that ports tend to increase GDP in the area where they are located. Moreover, the results indicate that there are large and positive spillover effects on the GDP of nearby regions. Economic expansion in non-port regions may also generate greater demand for port services in port regions.

The impact of port traffic on the city's economy was researched by Shan et al. [1] and the research examined three situations: (1) the economic impact of port activities on the local area where the port is located, (2) the spillover effects on neighbouring region, and (3) relationship and interaction between neighbouring ports since many ports were concerned that neighbouring competing ports were taking their jobs. They drew three important conclusions: first, freight traffic in the port significantly affects the economic growth of the city in which the port is located. Second, container freight traffic of larger ports is much more related to the economy than in smaller ports. Third, counter-intuitively, the freight traffic of competing seaports has a positive impact on the economy of the city. Zhao et al. [17] assumed that the previously considered strong link between ports and port cities was getting weak. They researched opportunities to attract investments and used data from the world's 50 largest container ports. The results show that, despite the positive relationship between ports and port cities, port cities do not show significant advantages over non-port cities in the context of attracting foreign direct investments. The competitiveness of a port city depends more on urban characteristics than on port factors. Cheung and Yip [18] researched the connection between the port and the economy of the city to which the port belongs, but from a different aspect. They researched how the economy affects 
the port and port production. They developed a model for studying the port production in relation to urban factors contributing to port operations based on the Cobb-Douglas production function. It has been recognized that the city's economy, i.e., economic factors, make the most significant contribution to port's growth, yet there are no consistent results on the effects of infrastructure and demographic factors on port operations.

Crescenzi and Rodriguez-Pose [3] researched the extent to which transport infrastructure affects regional economic growth in the European Union (EU) and introduced endogenous growth perspectives into the research. Empirical findings indicate that infrastructure investment and regional economic growth do not have a strong relationship; however, that EU regional economic growth results from a combination of investments in $R \& D$, an appropriate social filter, and a regional ability to attract migrants. The authors believe that funds should be redirected to investments in human capital and R\&D. Bilbao-Osorio and Rodriguez-Pose [19] researched the impact of investment in R\&D on innovation development as well as the impact of innovation on economic growth. The research results indicate that there is a positive connection between investment in R\&D and innovation. However, there is a difference between various research sectors: the private sector has a stronger connection than the public sector and higher education. The authors concluded that besides innovation, various other factors should be considered in order to understand the process of economic growth in the regions of the EU. Crescenzi [20] researched the relationship between innovation and regional growth in the EU regions. The author calculated his own innovation index, which was applied in the regression analysis. Empirical findings show relationship between innovation activities and regional growth as well as importance of human capital, especially in peripheral areas. If peripheral areas wish to keep up with central areas, their innovative activities must be supported by significant investments in human capital.

Authors researching the relationship of ports and the economy have, in most cases, proved that there is a positive link between the two. A major shortcoming of most papers is the lack of connection between various economic theories and research. The human capital aspect, investment in R\&D and other socio-economic conditions were not considered when determining the impact of seaports on the associated economies. Endogenous growth theory has served as a theoretical framework for the authors who researched the impact of transport infrastructure on economic growth; however, the impact of seaport operations in terms of endogenous growth theory has not yet been researched.

\section{Materials and Methods}

\subsection{Research Method}

The endogenous growth theory based on R\&D serves as a theoretical framework of this paper. Paul Romer [12] began the theory's development by building on Schumpeter's [21] ideas. Romer's model assumes that economic growth is driven by technological change and that technological change occurs through deliberate actions of individuals rather than random market events as was the case in the earlier neoclassical models. Later on, Grossman and Helpman [22,23] and Aghion and Howitt [24] developed similar models as well.

According to the endogenous growth theory, if economic policy changes it will affect long-term economic growth rates. The main goal for researching long-term economic growth is to find out why some countries are more developed and some less developed. Neoclassical models considered the emergence of convergence and diminishing returns, while models based on endogenous growth theory reject such assumptions. Models based on endogenous growth theory assume that less developed countries can stay underdeveloped while developed countries can continuously improve their standards with the creation of new ideas. The question is whether economic growth is the result of luck or thoughtful decisions and choices of different policies. Empirical data support the second thesis, i.e. that economic growth can be influenced by choosing optimal policies [25] (p. 20).

The endogenous growth theory based on R\&D states that economic growth is stimulated by technological changes that are the result of investment in R\&D and human activity. It is necessary 
to have quality human capital for innovation development and its implementation in later stages. Through the process of innovation, resources acquire new qualities while innovation activities generate new work activities and a new establishment of values. By such a process, knowledge is transformed into new value, and new value becomes the basis of competitiveness in dynamic markets [26] (p. 123). Innovations create incentives for long-term growth because they create opportunities for productivity improvements. Process innovation can reduce the time for production of the same product as well as achieve usage of fewer resources which leads to greater efficiency and productivity. Furthermore, innovations can affect the shift of the production possibilities frontier. If economies operate on a production possibilities frontier where all resources are engaged, by introducing innovation, the frontier can be moved, and production can be increased.

The literature that analyses and describes the endogenous growth theory and economic growth, considers that development of new ideas has to be supported by human capital $[13,14]$. Educational levels encourage economic growth because of their ability to create new technology and implement new findings and innovations. The basis of human capital is set in the theories of Theodor Schultz who proved that the social rate of return on investment in human capital in the American economy is higher than that based on physical capital, such as new factories and machines. The results of Shultz's research show that investing in human capital increases the wealth of the economy; therefore, it is believed that less-developed countries can advance by investing in education [27]. This theory was upgraded by Gary Becker, explaining that the costs of education, training and medical care could be considered an investment in human capital. Becker held that people cannot be separated from their knowledge, skills, health, or values in a way that they can separate from their financial and physical assets [28]. Therefore, people's education and skills contribute to the quality of human capital.

Bleaney et al. [29] implemented the endogenous growth model in researching the fiscal effects on growth. They tested the robustness of the results to alternative methods of isolating long-run effects, either by taking five-year averages or by estimating the model on the original annual data but with long lags. The results show that both approaches produce evidence of fiscal effects on growth; however, period averaging does not fully appear to capture long-run responses. Authors point out that dynamic panel data methods can improve results obtained from cross-section or static panel models. Caselli et al. [30] criticized existing cross-country empirical research on growth stating that there are two sources of inconsistency in cross-country empirical work connected with growth. More specifically, inconsistencies refer to the correlated individual effects and endogenous explanatory variables. They suggested that applying the generalized method of moments (GMM) instead, can solve those problems and produce better results. Levine et al. [31] researched the effects of financial intermediary development on economic growth using two approaches, the cross-sectional instrumental-variable estimator and the GMM dynamic panel estimators. Both approaches give consistent results that the exogenous component of financial intermediary development is positively associated with economic growth. However, the GMM estimator more comprehensively deals with problems caused by endogeneity, the use of lagged dependent variables in growth regressions and problems with any unobserved country-specific effects that in cross-sectional regression would be a part of the error term and potentially lead to biased coefficient estimates.

The economic impact of seaports on the regional economy will be researched by application of dynamic panel data analysis, more specifically, by using the two-step GMM. In dynamic panel data analysis, the present value of a particular variable depends on its previous values. Moreover, dynamic panel data estimation techniques use lags of the dependent variable as the new independent variable. However, by introducing the lagged value of the dependent variable as a new independent variable, the problem of endogeneity may occur; therefore, the new variable is introduced as an instrument. An instrument is a new variable that is not correlated with an error and affects a dependent variable but only through an independent variable. By introducing instruments for independent variables, the GMM procedure enables the solution of the problem of endogeneity of variables. Two kinds of transformation method can be used as GMM estimators: first-difference 
transformation, known as one-step GMM, and second-order transformation, known as two-step GMM. One-step GMM has some limitations, such as if a variable's recent value is missing, it can result in the loss of too many observations since a variable's past value is deducted from its current value $[32,33]$.

The GMM method was first derived by Arellano and Bond [34]. Later, Arellano and Bover [35] and Blundell and Bond [36] found a potential weakness in the Arellano-Bond estimator since the lagged levels are often poor instruments for first differenced variables. The Arellano-Bover/Blundell-Bond estimator modifies the Arellano-Bond estimator by the additional assumption that the first differences of the instrumental variables are uncorrelated with fixed effects. Their modification includes lagged levels and lagged differences. This allows for the introduction of multiple instruments and can improve efficiency. The estimator builds a system of two equations, the original equation and the transformed one [32] (p. 86). The lagged values of the dependent variable are used as instruments to account for the endogeneity problem, as mentioned before. Furthermore, in order to avoid potential data loss, Arellano and Bover [35] recommended the use of a second-order transformation (two-step GMM). It is shown that two-step estimation is more efficient than the first-step estimation, yet it can have some shortcomings such as producing biased results when using finite samples.

In this research, GDP per capita expressed in purchasing power standards (PPS) is a dependent variable that represents regional economic growth. GDP per capita growth is influenced by its values from the previous year, which is why dynamic panel analysis is used. GDP per capita expressed in terms of purchasing power standard enables the comparison of regions of different sizes and eliminates differences in prices among them [37].

\subsection{Data Collection}

The research sample consists of 107 port regions of the EU having NUTS 2 classification level. The NUTS classification (Nomenclature of Spatial Units for Statistics, Fr. Nomenclature des unités territoriales statistiques) is a hierarchical system for dividing up the economic territory of the EU and the United Kingdom for the purposes of official statistics. The data were observed for 11 consecutive years, i.e., from 2005 to 2015 [37-44]. The study included the regions of the following countries: Belgium, Bulgaria, Croatia, Cyprus, Denmark, Estonia, Finland, France, Germany, Ireland, Italy, Latvia, Lithuania, Malta, The Netherlands, Poland, Portugal, Romania, Spain, Sweden and the United Kingdom. Greece and Slovenia are excluded from the research, although they have data on freight traffic in seaports but have no data on investment in R\&D. Figure 1 shows the regions included in the research together with the interval of the amount of freight traffic in each individual region.

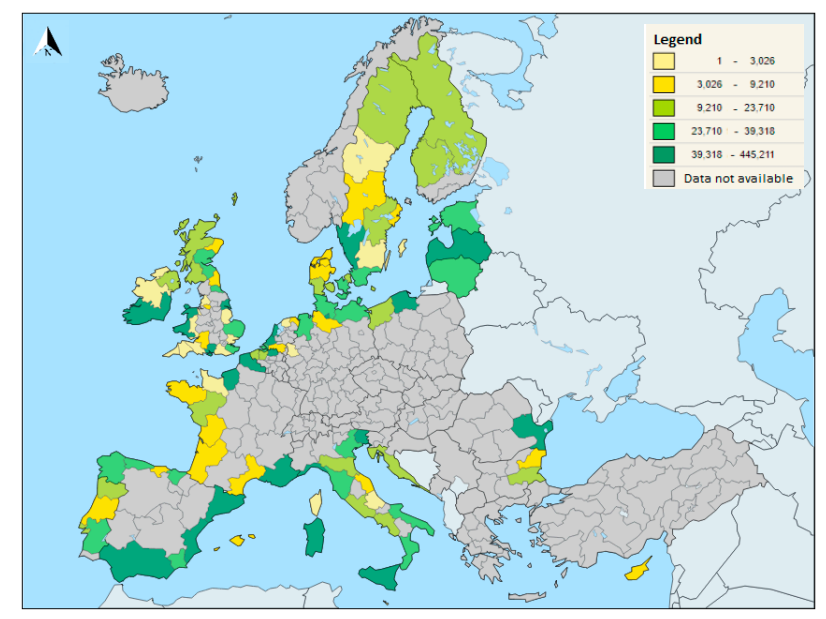

Figure 1. The regions of the European Union included in the research (adapted from European Commission (Eurostat). Maritime transport of freight by NUTS 2 regions-map. 2016. [45] with permission from Eurostat, 2020.). 


\subsection{Variables}

The impact of port activities on regional economies is researched through a regression model in which the dependent variable represents regional economic growth. GDP per capita (GDPpc) is used as a dependent variable, according to the literature $[1,3,6,15,16,19]$. Independent variables include seaports' activities, variables associated with endogenous growth theory, and a set of control variables associated with regional economic growth.

The main independent variable is freight traffic in seaports (Freight); it is measured by the tonnage throughput of all types of freight and is a widely accepted indicator of seaport operations and port productivity $[1,6,8,9,15,18]$. There are other metrics that measure the seaports' activities such as profit, annual number of vessels or number of passengers; however, those metrics are not available on regional level or are not suitable for this study. Some prior research noted that the economic impact of passengers is not particularly relevant, since a significant share of that traffic is related to transit passengers [6,8]. Regions have various numbers of seaports located within them; therefore, data for each region considers the total freight flow within the region.

In order to research the effect of factors relevant to endogenous growth theory, the variables of the investment in the research and development (RD) and human capital (HC) are also included. From the perspective of endogenous growth theory, the creation of new ideas and knowledge is main driver of the long-term economic growth. Innovative and absorptive possibilities tent to be proxied by R\&D in the empirical literature [3]. It is often assumed that investments in R\&D will lead to greater applied research and will increase the number of innovations. Consequently, when new innovations are introduced to the production process and enter the market, they affect economic growth. This perception states that higher investments in R\&D lead to higher innovative capacity and higher economic growth which can be defined as a linear perception. It places investments in $R \& D$ in the center of technological progress and eventually economic growth [46] (p. 53-54). In the study, human capital was represented as the percentage of the population aged 25-64 who completed tertiary education, all done according to the following authors: Crescenzi and Rodriguez-Pose [3], Crescenzi [20], Hong et al. [47] and Ferrari et al. [9]. The European Commission also explains human capital as part of educational achievements [48]. The ability to explain differences in regional growth that is related to innovative activities, is based on an understanding of the mechanism through which knowledge is created, implemented and affects the economic growth. In most cases, technological progress depends on human knowledge which is primarily needed to develop a new technology or innovation. Secondly, knowledge is needed for implementation of newly developed technology or innovation. Therefore, higher education is taken as a variable that represents human capital because it is assumed that highly educated people will participate in $R \& D$ activities as well as in their implementation activities $[3,19]$.

A set of control variables was also included in the research, all in order to encompass factors other than the sole effect of the port. These variables are commonly used in literature on economic growth and are found to be associated with economic growth $[3,9,19,20,46,47,49]$. Therefore, it is necessary to introduce them in the work, although they are not in the focus of the research. The level of unemployment (Unempl) in introduced as an indicator of the presence of individuals whose inadequate skills interfere with possibilities of being involved in productive work as well as the indicator of the rigidity of the labour market $[46,50]$. The population of each specific region (Pop) was used as the measure of the demographic structure and it represents the change of human resources that enter the labour market. New skills and knowledge might enter the market when the positive population change occurs [46] (p. 56). Moreover, new human resources entering the labour market can deal with challenge of an ageing population who might implement new ideas and technologies slower. Trade openness (Open) controls for the openness of each individual regional economy and shows the percentage of imports and exports in GDP. Trade openness in general is good for the growth of the economy since it can create new jobs and provide new opportunities for local companies to amplify productivity and innovation because of the stronger competition. The last control variable is 
investment in transport infrastructure (Transport) since it is widely researched in literature as a driver of economic growth [16,51-56]. Transport infrastructure has importance for seaports because of the freight distribution to final destinations. Moreover, it is easier to adopt new technologies where the infrastructure is developed [47] (p. 742). Table 1 shows a list of used variables.

Table 1. The list and explanation of the variables

\begin{tabular}{ccc}
\hline Dependent Variable & Description & Formulation \\
\hline GDPpc & Gross domestic product per capita & $\begin{array}{c}\text { Expressed in purchasing power standards } \\
\text { (PPS) in EUR }\end{array}$ \\
\hline Independent Variables & Description & Formulation \\
\hline Freight & Freight traffic in seaports & 1000 tons \\
\hline RD & Investment in research and development & $\%$ of GDP \\
\hline HC & Human Capital & $\begin{array}{c}\% \text { population between 25-64 who } \\
\text { completed tertiary education }\end{array}$ \\
\hline Control Variables & Description & Formulation \\
\hline Unempl & Unemployment rate & $\%$ of unemployed in total work force \\
\hline Pop & Population & $\begin{array}{c}\% \text { of total population change } \\
\text { per 1000 persons }\end{array}$ \\
\hline Open & Trade openness & $\%$ of imports and exports in GDP \\
\hline Transport & Investment in transport infrastructure & $\%$ of GDP \\
\hline
\end{tabular}

Data for all variables were available at NUTS 2 level, except for the transport infrastructure and trade openness data, which were only available at the aggregate level. Therefore, the missing regional data were self-calculated as follows. The share of regional GDP per capita in the total GDP per capita of the corresponding country was calculated and then multiplied with the aggregate data related to transport infrastructure. In such way, the regional data for transport infrastructure were obtained. The same procedure was applied to trade openness. Eurostat lacks many data on investment in R\&D; therefore, the missing values, where possible, were calculated by linear interpolation.

\subsection{Model Specification}

In order to research the relationship between regional economic growth and seaport operations, as well as other previously described factors, a model of dynamic panel analysis was proposed. The model is expressed as follows:

$$
\ln G D P p c_{i t}=\beta_{0}+\beta_{1} \ln G D P p c_{i t-1}+\beta_{2} \operatorname{lnFreight}_{i t}+\beta_{3} R D_{i t}+\beta_{4} H C_{i t}+\text { Control }_{i t}+\lambda_{t}+u_{i t}
$$

where $\ln G D P p c_{i t}$ is the logarithmic value of gross domestic product per capita for the region $i$ and time $t, \ln G D P p c_{i t-1}$ is the logarithmic value of gross domestic product per capita for the region $i$ and time $t-1, \ln$ Freight $t_{i t}$ is the logarithmic value of freight traffic in seaports for the region $i$ and time $t, R D_{i t}$ is the value of investment in R\&D for the region $i$ and time $t, H C_{i t}$ is an indicator of human capital for the the region $i$ and time $t$, Control ${ }_{i t}$ represents control variables that include unemployment rate, population, trade openness and investment in transport infrastructure for the region $i$ and time $t$ $\left(\right.$ Control $_{i t}=$ Unempl $_{i t}+$ Pop $_{i t}+$ Open $_{i t}+$ Transport $\left._{i t}\right) \cdot \lambda_{t}$ represents the time effects, $u_{i t}$ relation error and $\beta_{1}, \beta_{2}, \beta_{3}, \mathrm{i} \beta_{4}$ are the coefficients.

In order to determine the significance of each of the independent variables separately, four model variations were introduced. The first variation includes freight traffic as an independent variable and a set of control variables that are included in each variation of the model.

Model 1:

$$
\ln G D P p c_{i t}=\beta_{0}+\beta_{1} \operatorname{lnGDPpc_{it-1}}+\beta_{2} \operatorname{lnFreight}_{i t}+\text { Control }_{i t}+\lambda_{t}+u_{i t}
$$


The second variation includes freight traffic and investment in R\&D in order to examine the importance of R\&D for economic growth.

Model 2:

$$
\ln G D P p c_{i t}=\beta_{0}+\beta_{1} \operatorname{lnGDPpc} c_{i t-1}+\beta_{2} \operatorname{lnFreight}_{i t}+\beta_{3} R D_{i t}+\text { Control }_{i t}+\lambda_{t}+u_{i t}
$$

The third variation includes freight traffic and human capital which according to endogenous growth theory is claimed to be of great importance for economic growth.

Model 3:

$$
\ln G D P p c_{i t}=\beta_{0}+\beta_{1} \operatorname{lnGDPpc}_{i t-1}+\beta_{2} \operatorname{lnFreight}_{i t}+\beta_{3} H C_{i t}+\text { Control }_{i t}+\lambda_{t}+u_{i t}
$$

Finally, the fourth variation is a model proposed at the beginning; it encompasses all defined variables and aims to examine the overall impact of the main independent variables (freight traffic, $R \& D$ investment and human capital) on economic growth.

Model 4:

$$
\ln G D P p c_{i t}=\beta_{0}+\beta_{1} \operatorname{lnGDPpc} i t-1+\beta_{2} \operatorname{lnFreight}_{i t}+\beta_{3} R D_{i t}+\beta_{4} H C_{i t}+\text { Control }_{i t}+\lambda_{t}+u_{i t}
$$

To consider the possibility of a non-linear relationship between dependent variable (economic growth) and independent variables, logarithmic transformation was applied in models. The logarithmic forms of variables also ensure that the estimated coefficients are robust to the measurement units of the variables. The logarithmic transformation is a routine procedure in the maritime economics literature as well as economics literature in general $[1,6,18,51]$.

\section{Results}

\subsection{Descriptive Statistical Analysis}

Before testing the model, a descriptive statistical analysis was performed and the presence of correlation was tested. Table 2 shows the descriptive statistics for each individual variable.

Table 2. Descriptive statistics of variables.

\begin{tabular}{cccccc}
\hline Variable & $\begin{array}{c}\text { Number of } \\
\text { Observations }\end{array}$ & Mean & $\begin{array}{c}\text { Standard } \\
\text { Deviation }\end{array}$ & Minimum & Maximum \\
\hline GDPpc & 1175 & $25,269.19$ & 7617.80 & 7100.00 & $59,500.00$ \\
\hline Freight & 1176 & $31,178.99$ & $45,982.07$ & 240.00 & $44,8598.00$ \\
\hline RD & 1136 & 1.39 & 1.02 & 0.06 & 5.44 \\
\hline HC & 1165 & 26.96 & 8.73 & 7.30 & 52.20 \\
\hline Unempl & 1161 & 9.26 & 5.55 & 2.00 & 37.00 \\
\hline Pop & 1167 & 4.27 & 7.35 & -28.90 & 54.80 \\
\hline Open & 1175 & 14.67 & 37.31 & 0.82 & 325.86 \\
\hline Transport & 1173 & 0.28 & 0.50 & 0.03 & 3.70 \\
\hline
\end{tabular}

The standard deviation shows greater variations in GDP per capita, which means that there are significant differences in the development of EU port regions. Such a phenomenon was anticipated because different EU member states have significant differences in the development of their economies, which is reflected in the respective regions. The 'freight traffic' variable in seaports has larger variations as well, which indicates that there are large differences in the levels of seaport operations in different regions. The standard deviation of trade openness has a slightly higher value indicating differences between the percentage of imports and exports in GDP in different port regions. The variables 
'investment in transport infrastructure' and 'investment in research and development' have the least standard deviations, which are expected since the ratios of investment within the regions and over the years do not change much. Testing the model aims to find out what affects the growth of regions and what are the potential growth factors that need to be addressed. The correlation between the variables was verified before testing the model. Table 3 shows the correlation coefficients of the variables.

Table 3. Correlation coefficients.

\begin{tabular}{ccccccccc}
\hline & ln GDPpc & ln Freight & RD & HC & Unempl & Pop & Open & Transport \\
\hline ln GDPpc & 1 & - & - & - & - & - & - & - \\
\hline $\ln$ Freight & 0.08 & 1 & - & - & - & - & - & - \\
\hline RD & 0.54 & 0.19 & 1 & - & - & - & - & - \\
\hline HC & 0.46 & 0.00 & 0.47 & 1 & - & - & - & - \\
\hline Unempl & -0.36 & 0.05 & -0.25 & -0.16 & 1 & - & - & - \\
\hline Pop & 0.35 & -0.16 & 0.16 & 0.18 & -0.16 & 1 & - & - \\
\hline Open & -0.09 & -0.01 & -0.07 & 0.04 & -0.02 & -0.07 & 1 & - \\
\hline Transport & -0.19 & 0.08 & -0.04 & 0.07 & 0.02 & -0.22 & 0.76 & 1 \\
\hline
\end{tabular}

A positive or negative correlation that is greater than 0.80 serves as a threshold for a correlation presence [57]. The review of the correlation coefficients shows that no coefficient exceeds the threshold, which indicates the absence of multicollinearity.

\subsection{Model Testing}

Freight traffic as well as investment in R\&D and human capital is expected to have a positive impact on economic growth. Furthermore, unemployment and population are expected to have a negative impact on economic growth. The model uses GDP per capita as a dependent variable; therefore, if the population increases, a decline in GDP per capita is expected. Trade openness, investment in transport infrastructure and GDP per capita for the previous year are expected to have a positive impact on economic growth. The results of testing the model in the program package STATA are presented in Table 4.

Models were estimated using the two-step system GMM estimator. The two-step GMM estimator is asymptotically efficient and robust to all patterns of heteroskedasticity and cross-correlation. However, it might show certain problems when it is being used with small samples. In sample sizes where the equivalent tests based on the one-step procedure are accurate, the two-step asymptotic $t$-statistics are too high and the two-step asymptotic standard errors are too small. Therefore, there is an overfitting bias in small samples that have many instruments and reweighting empirical moments based on their own estimated covariances. This can surpass the statistical power and reduce the importance of observations that do not fit the model well. Therefore, in line with Windmeijer's [58] correction, estimations of the two-step GMM models with corrected standard errors and $t$-tests were made that are as reliable.

Tests for autocorrelation and instrument validity are shown in the previous table. The Hansen test confirms the null hypothesis which claims that the instruments are valid and not correlated with the stochastic error of the model. This is confirmed with a p-value greater than 0.05 . Since a two-step system GMM estimator is used, it is necessary to rely on a Hansen test rather than the Sargan test because the Sargan test is not robust to residual heteroskedasticity [59]. Arellano-Bond for serial correlation in the first residual differences rejects the hypothesis of non-existence of the first order serial correlation in all variations of the model, while the same hypothesis cannot be rejected for higher levels, which is desirable. 
Table 4. Results of the model testing.

\begin{tabular}{|c|c|c|c|c|}
\hline & Model 1 & Model 2 & Model 3 & Model 4 \\
\hline VARIABLES & $\ln$ GDPpc & $\ln$ GDPpc & $\ln$ GDPpc & $\ln$ GDPpc \\
\hline \multirow[t]{2}{*}{ L.In GDPpc } & $0.967^{* * *}$ & $0.959^{* * *}$ & $0.952 * * *$ & $0.949^{* * *}$ \\
\hline & $(0.0139)$ & $(0.0156)$ & $(0.0151)$ & $(0.0156)$ \\
\hline \multirow[t]{2}{*}{ ln Freight } & $0.00924^{* *}$ & $0.00891 * *$ & $0.00966^{* * *}$ & $0.00805^{* *}$ \\
\hline & $(0.00374)$ & $(0.00384)$ & $(0.00345)$ & $(0.00322)$ \\
\hline \multirow[t]{2}{*}{$\mathrm{RD}$} & - & $0.00695 *$ & - & 0.00204 \\
\hline & - & $(0.00384)$ & - & $(0.00431)$ \\
\hline \multirow[t]{2}{*}{$\mathrm{HC}$} & - & - & $0.000866^{* *}$ & $0.000698 *$ \\
\hline & - & - & $(0.000338)$ & $(0.000364)$ \\
\hline \multirow[t]{2}{*}{ Unempl } & $-0.00246^{* * *}$ & $-0.00221^{* * *}$ & $-0.00235^{* * *}$ & $-0.00230 * * *$ \\
\hline & $(0.000424)$ & $(0.000439)$ & $(0.000449)$ & $(0.000389)$ \\
\hline \multirow[t]{2}{*}{ Open } & $0.000147^{* *}$ & $0.000139 * * *$ & $0.000185^{* * *}$ & $0.000154^{* * *}$ \\
\hline & $\left(6.11 \times 10^{-5}\right)$ & $\left(4.94 \times 10^{-5}\right)$ & $\left(5.43 \times 10^{-5}\right)$ & $\left(4.74 \times 10^{-5}\right)$ \\
\hline \multirow[t]{2}{*}{ Pop } & $-0.000748^{* * *}$ & $-0.000747^{* *}$ & $-0.000703^{* *}$ & $-0.000748^{* *}$ \\
\hline & $(0.000281)$ & $(0.000318)$ & $(0.000283)$ & $(0.000302)$ \\
\hline \multirow[t]{2}{*}{ Transport } & -0.00465 & -0.00437 & $-0.0111^{*}$ & -0.00894 \\
\hline & $(0.00615)$ & $(0.00540)$ & $(0.00594)$ & $(0.00558)$ \\
\hline Time effects included & Yes & Yes & Yes & Yes \\
\hline \multirow[t]{2}{*}{ Constant } & 0.277 * & $0.335^{* *}$ & $0.401 * *$ & $0.428^{* * *}$ \\
\hline & $(0.150)$ & $(0.165)$ & $(0.154)$ & $(0.158)$ \\
\hline Observations & 1058 & 1035 & 1058 & 1035 \\
\hline Number of regID & 107 & 107 & 107 & 107 \\
\hline Hansen test ( $p$-value) & 0.209 & 0.817 & 0.665 & 0.960 \\
\hline AR (1) test ( $p$-value) & 0.000 & 0.000 & 0.000 & 0.000 \\
\hline $\mathrm{AR}(2)$ test ( $p$-value) & 0.717 & 0.733 & 0.748 & 0.770 \\
\hline
\end{tabular}

Standard errors in parentheses; ${ }^{* * *} p<0.01,{ }^{* *} p<0.05, * p<0.1$; Notes: In all model specifications, dependent variables with maximum of two lags are used as valid instruments. Models also include temporal dummy variables. Suboption 'collapse' is used for variable that represents GDP per capita. This option creates one instrument for each variable and lag distance, rather than one for each time period, variable and lag distance. In small samples, 'collapse' can avoid the bias that arises as the number of instruments climbs toward the number of observations.

The impact of freight traffic on economic growth is examined by the first model and the results of the research show that the relationship exists. The estimated coefficient is 0.00924 and is statistically significant at the level of $5 \%$, which indicates that if freight traffic increases by $10 \%$, the regional GDP per capita will increase, on average, by $0.0924 \%$. The control variables in the model are statistically significant and have expected positive or negative impact on economic growth. Unemployment is found to negatively affect economic growth with statistical significance of $1 \%$; therefore, if unemployment increase by 10 percentage points, the regional GDP per capita will decrease by $0.0246 \%$, on average. Trade openness as phenomenon that should encourage the growth of the economy is found to be statistically significant at $5 \%$ and its results are interpreted as follows: if trade openness increases by 10 percentage points, the regional GDP per capita will increase by $0.00147 \%$, on average. Population was expected to have a negative impact on economic growth which was proven at $1 \%$ statistical significance. More precisely, if population increases by 10 percentage points, regional economic growth will decrease, on average, by $0.00748 \%$. The exception is variable investments in transport infrastructure which are 
found to be statistically insignificant. Statistical insignificance can be explained by small variations in transport infrastructure within regions. From the aggregate level of perspective, the assumption is that investment in transport infrastructure would be significant since there are large differences in transport infrastructure at the level of entire economies, yet the variation within each region in each year is small.

From the perspective of endogenous growth theory, the creation of new knowledge and ideas is considered a key driver of long-term growth, productivity and income. Therefore, Model 2 introduced a variable representing $R \& D$. The results of testing of the Model 2 indicate that investment in R\&D has a positive effect on economic growth with $10 \%$ statistical significance. If investment in R\&D increases by 10 percentage points, regional economic growth will increase by $0.0695 \%$, on average. Freight traffic is also included in the model as the most important independent research variable and is statistically significant at $5 \%$ and affects the economic growth. More precisely, if freight traffic increases by $10 \%$, the regional GDP per capita will increase, on average, by $0.0891 \%$. As in Model 1 , the control variables are statistically significant and have the expected positive or negative impact, except for investments in transport infrastructure that is found to be statistically insignificant. Unemployment has negative impact on regional economic growth: if unemployment increases by 10 percentage points, regional economic growth will decrease on average by $0.0221 \%$, with statistical significance of $1 \%$. Trade openness has a positive impact on regional economic growth and is statistically significant at $1 \%$; therefore, if trade openness increases by 10 percentage points, the regional GDP per capita will increase by $0.00139 \%$, on average. Population has the expected, negative, impact on regional economic growth with $5 \%$ statistical significance, so the interpretation of the results obtained is the following: if population increases by 10 percentage points, the regional GDP per capita will decrease, on average, by $0.00747 \%$.

In addition to creating new knowledge and ideas, it is also necessary to absorb and implement newly produced knowledge as well as to adapt to new ideas; therefore, the need to test the impact of human capital on economic growth was developed. Quality management of seaports, as well as investment in R\&D, are strongly influenced by an adequate socio-economic environment. The region's response to new investments can be linked to educational achievements and productive use of human resources. Considering the constraints of regional data, the data on the share of the population with completed tertiary education in the total population were used as an indicator of human capital. Model 3 tested the impact of human capital on economic growth and determined its impact with $5 \%$ statistical significance. The estimated coefficient is 0.000866 , which means that if human capital increases by 10 percentage points, the regional GDP per capita will increase, on average, by $0.00866 \%$. Freight traffic is also one of the independent variables of Model 3, and testing has proven its statistical significance at $1 \%$ and the existence of an impact on GDP per capita. Therefore, if freight traffic increases by $10 \%$, the regional GDP per capita will increase, on average, by $0.0966 \%$. The control variables are statistically significant and have the expected positive or negative impact. Increasing unemployment has negative impact on regional economic growth, meaning that if unemployment increases by 10 percentage points, the regional GDP per capita will decrease on average by $0.0235 \%$, with statistical significance of $1 \%$. Trade openness is statistically significant at $1 \%$ and its interpretation is the following: if trade openness increases by 10 percentage points, the regional GDP per capita will increase on average by $0.00185 \%$. If the population increases, GDP per capita is expected to decrease which is supported by the results showing that if population increases by 10 percentage points, regional economic growth will decrease, on average, by $0.00703 \%$, with $5 \%$ statistical significance. Results of investments in transport infrastructure are found to be statistically significant in this model; however, with negative impact: if transport infrastructure increases by 10 percentage points, regional economic growth will decrease, on average, by $0.111 \%$, with $1 \%$ statistical significance.

Model 4 included all independent variables of the research and the results indicate, as in all previous models, that freight traffic has a positive impact on regional economic growth. The estimated coefficient of the freight in Model 4 is 0.00805 and it is statistically significant at the level of $5 \%$. This result indicates that if freight traffic increases by $10 \%$, regional GDP per capita will increase by 
$0.0805 \%$, on average. The variable that represents $R \& D$ is found to be statistically insignificant in this model; however, the variable that represents human capital is statistically significant at $10 \%$ and its interpretation reports: if human capital increases by 10 percentage points, the regional GDP per capita will increase, on average, by $0.00698 \%$. Unemployment is statistically significant at $1 \%$ and is expected to have a negative impact on regional economic growth: if unemployment increases by 10 percentage points, the regional GDP per capita will decrease on average by $0.0230 \%$. Trade openness is expected to have positive impact on regional economic growth which was proven by results that are interpreted as follows: if trade openness increases by 10 percentage points, the regional GDP per capita will increase on average by $0.00154 \%$, with $1 \%$ statistical significance. Population is statistically significant at $5 \%$ and has an expected negative impact on regional economic growth; more precisely, if population increases by 10 percentage points, regional economic growth will decrease, on average, by $0.00748 \%$. As in previous models, investments in transport infrastructure are found to be statistically insignificant; therefore, more detailed conclusions could not be drawn.

To conclude, freight traffic in seaports has a positive impact on the economic growth of the host's region, which is proven in all proposed models (Model 1, Model 2, Model 3 and Model 4) and is in accordance with theoretical assumptions.

\section{Discussion}

The results of the research show that the operation of seaports has a positive impact on the economic growth of their regions and that it is important to pay attention to other drivers of regional economic growth such as human capital and investment in R\&D. Furthermore, the results imply the need for constant improvement of seaport operations and the implementation of new knowledge and technologies in business. Seaports that invest in new technologies and sophisticated data processing systems have greater preconditions to be successful in their business.

According to the endogenous growth theory based on $R \& D$, the creation of new ideas is an important factor that leads to constant growth of the economy. It is believed that economies that generate new ideas will not reach a saturation point where economic growth stagnates. Moreover, it is believed that creating new ideas avoids convergence, which means that underdeveloped economies grow faster because they start from the minimum and copy others, while stronger economies grow more slowly. The theory states that convergence does not have to happen at all, i.e., developed countries can continuously improve their living standard, while less developed countries can remain underdeveloped forever. The creation and implementation of innovations and new technologies are important factors of seaports operations because they affect their competitive position and the development of the business process. Due to the nature of the business, users can easily transfer freight from one port to another if they are not satisfied with the service, which is another reason why seaports must strive to provide quality service based on modern technology [60] (p. 1741).

The share of R\&D investment in GDP was taken as a variable representing research and development. However, as with the other proxy variables, there are limitations that need to be considered when describing research results. Investments in $R \& D$ can have a diverse impact in terms of strength and time. Investments that are not related to formal $R \& D$, for example investments in existing products and processes, can be neglected and not considered; however, they can produce significant economic effects. On the other hand, large investments in new areas can take a lot of time to become profitable [3] (p. 14). These effects limit the ability to fully assess the impact of R\&D investment on economic growth.

The educated population contributes to the success of the region as well as the seaports since new technologies require a higher level of education due to a more advanced handling system. The results of the research confirm the positive impact of human capital on regional economic growth; however, the impact is relatively small. One of the reasons for this is the nature of the data because the proxy variable is tertiary education, meaning higher education, while a better indicator of human capital would be the Human Development Index for which there are no regional data. Furthermore, 
in order for the population to reach tertiary education, it takes many years and a lot of resources, so the impact on economic growth is dispersed. It is also necessary to consider that this is a regional impact, while the impact of human capital on the entire economy is certainly greater.

Regions should encourage the development of new ideas; however, at the same time they should create good conditions for their development and implementation [61] (p. 598). First of all, they should have an educated population, i.e., quality human capital that will be able to create innovations and implement them into business. Furthermore, a low level of unemployment is needed, as employed people are more inclined to implement new technological solutions than the unemployed. Finally, it is necessary for the regions to be oriented towards the industry sector and the production sector because such regions are more inclined to business innovation when compared to the regions dealing with agriculture [19]. Port regions belong to the aforementioned industry segment and are expected to implement new technological advances, considering that for seaports adapting to new trends is one of the prerequisites for maintaining competitiveness.

Transport infrastructure is proved to be a statistically insignificant variable; therefore, it is not possible to draw more detailed conclusions with the exception in Model 2 where the variable is statistically significant but has a negative impact on economic growth. One of the reasons for this may be that the effects of investing in transport infrastructure can only be seen after several years. This can also be justified by the fact that if there is a developed economy, there will already be quality infrastructure in place. This means that quality infrastructure is a consequence of a developed economy, and not the other way around whereby infrastructure is the driver of the economy. Furthermore, the variations in transport infrastructure within regions are small, which may justify the statistical insignificance of the variable. The assumption is that investment in transport infrastructure would be significant if the aggregate level was considered, while the variation within the region from year to year is small and no obvious differences can be seen. Although the EU seeks to encourage the development of human capital and the investment in R\&D, it is necessary to note the partial underestimation of these factors in relation to investments in transport infrastructure. Transport infrastructure is the focus of many EU strategies, the main one being the development of an integrated European Transport Network (TEN-T) [62] (p. 153).

The nature of seaport operations is dynamic, and prone to changes and new trends, which is linked to investment in R\&D and new technologies. Trends in seaports are mostly directed to digitalization and the mechanization of ports. Furthermore, the maritime labour market is increasingly looking for highly educated people who have knowledge of new technologies and communication methods (application of clouds in business, blockchain technology, drones, 3D printers, 5G networks). Technology is a process that does not end in one cycle yet forms a network that needs constant upgrading. At the same time, the development of new technology and its application contribute to an efficient transport system, which is important for the development of regional economic mobility. It is anticipated that the development tendencies of seaports in the future will be oriented to full digitalization where almost all port operations will be performed by using information and communication technology. Therefore, the innovative capabilities of seaports and associated regions and quality human capital are assumed to be a precondition for maintaining competitiveness and developing a positive business trend. However, elements such as investment in R\&D and human capital are often underestimated in relation to investment in transport infrastructure, not only in the EU but also in most of the world. Guidelines for the diversion of funds could, rather, support the investments in human capital development and investments in R\&D as they have proven to be significant drivers of economic growth that could ultimately lead to a better return on public funds.

The limitations of the model are reflected in the availability of data, as data at the regional level are less complete and less diverse than data at the aggregate level. Furthermore, the limitations are also reflected in the variables of the model. If data availability allows, a variable representing $R \& D$ can be represented by introducing a different proxy variable, such as the number of patents or the calculation of new innovation index. This could lead to new conclusions about the importance of developing new 
ideas and their impact on regional growth. Human capital can also be defined through other variables such as the Human Development Index for which no data are currently available for the regional level. It is certain that there are other variables that can be tested and interpreted in the context of measuring the impact of seaports on regional economies within endogenous growth theory.

Further research can focus not only on model testing on new data sets, but also on the implementation of non-included variables that affect economic growth while improving seaport operations. Recommendations for future research may go in the direction of grouping port regions according to macroeconomic indicators. Furthermore, the impact of seaports on developed and less developed regions can be analyzed and their differences defined. The proposed model can be tested on a sample of different economies, i.e., on other data sets that are not exclusively related to the EU, which would provide insight into the importance of seaports in different areas.

\section{Conclusions}

This paper researches the impact of seaports on the economic growth of EU port regions. It is recognized in literature that the seaports have impact on their economies on aggregate, regional or city levels while there are several academic contributions using economic theories as research frameworks, to the best of our knowledge. This paper contributes to the effort to fill this gap by researching the relationship between seaports and economic growth from the aspect of endogenous growth theory. It estimates the relationship of seaports and their 107 corresponding port regions in the EU through panel data analysis over the time period 2005-2015.

Specifically, using the GDP per capita expressed in purchasing power standards as a proxy for the regional economic growth and freight traffic in seaports as a proxy for the seaports' operations, the regression was performed along with a set of control variables. In order to apply endogenous growth theory, variables that represent R\&D and human capital were introduced in the research.

Empirical findings in this paper show that seaports have an impact on regional economic growth, respectively, they tend to increase GDP per capita in the area where they are located. The results are statistically and economically significant and show that an increase in seaports' freight traffic by $10 \%$ tends to increase GDP per capita in the observed region by about $0.0805-0.0966 \%$. Investments in R\&D have a positive impact on regional economic growth as well. More precisely, increasing investments in R\&D by 10 percentage points tends to increase GDP per capita by $0.0695 \%$, on average. Human capital is also significant and its estimates suggest that increasing human capital by 10 percentage points tends to increase GDP per capita by $0.00866 \%$, on average. Results that were not expected are associated with transport infrastructure. In Model 2 the variable is statistically significant, yet it is found to have a negative impact on economic growth. In other model variations, coefficients of the variable that represents transport infrastructure are statistically insignificant; therefore, detailed conclusions about the importance of transport infrastructure could not be drawn. Since the EU invests large sums in transport infrastructure, the question arises as to whether some of these funds could be redirected to other sectors. The guidelines for resource redistribution should be further researched.

Overall results seem to be in accordance with the theoretical background and maritime economics literature that put a focus on seaports as drivers of regional economic growth. This paper makes several contributions to the literature; it provides empirical evidence for the existence of the relationship between seaports and their respective regional economies. Moreover, it refers to the endogenous growth theory as a theoretical framework that advocates the importance of human capital and creation of new ideas. Last, it questions the great importance given to investments in transport infrastructure in regards to investments in $R \& D$ and human capital that were found to have impact on regional economic growth of the EU port regions.

Author Contributions: G.M. developed the original idea for this study. G.M. was responsible for methodology, data collection and data analysis. G.M. and A.J. took part in the formal analysis and validation. A.J. was responsible for writing and preparation of the original draft version. D.Š.-A. led the article supervision and data validation. All authors have read and agreed to the published version of the manuscript. 
Funding: This research was funded by the project "Kompleksni multiplikativni učinci morskih luka i njihov utjecaj na gospodarstvo" (University of Rijeka, Faculty of Maritime Studies) and by the project number [uniri-drustv-18-166] (University of Rijeka).

Conflicts of Interest: The authors declare no conflict of interest.

\section{References}

1. Shan, J.; Yu, M.; Lee, C.Y. An empirical investigation of the seaport's economic impact: Evidence from major ports in China. Transp. Res. Part E Logist. Transp. Rev. 2014, 69, 41-53. [CrossRef]

2. Fujita, M.; Krugman, P.; Venables, A.J. The Spatial Economy: Cities, Regions, and International Trade; The MIT Press: Cambridge, MA, MA, USA, 1999.

3. Crescenzi, R.; Rodríguez, P.A. Infrastructure and regional growth in the European Union. Pap. Reg. Sci. 2012, 91, 487-513. [CrossRef]

4. Gripaios, P.; Gripaios, R. The Impact of a Port on its Local Economy: The Case of Plymouth. Marit Policy Manag. 1995, 22, 13-23. [CrossRef]

5. Cohen, J.; Monaco, K. Ports and highways infrastructure: An analysis of intra- and interstate spillovers. Int. Reg. Sci. Rev. 2008, 31, 257-274. [CrossRef]

6. Bottasso, A.; Conti, M.; Ferrari, C.; Tei, A. Ports and regional development: A spatial analysis on a panel of European regions. Transp. Res. Part A Policy Pract. 2014, 65, 44-55. [CrossRef]

7. Aschauer, D.A. Is public expenditure productive? J. Monet. Econ. 1989, 23, 177-200. [CrossRef]

8. Bottasso, A.; Conti, M.; Ferrari, C.; Merk, O.; Tei, A. The impact of port throughput on local employment: Evidence from a panel of European regions. Transp. Policy 2013, 27, 32-38. [CrossRef]

9. Ferrari, C.; Percoco, M.; Tedeschi, A. Ports and local development: Evidence from Italy. Int. J. Transp. Econ. 2010, 37, 9-30.

10. Notteboom, T.E.; Winkelmans, W. Structural changes in logistics: How will port authorities face the challenge. Marit Policy Manag. 2001, 28,71-89. [CrossRef]

11. Villaverde, C.J.; Coto, M.P. Port economic impact: Methodologies and application to the port of Santander. Int. J. Transp. Econ. 1998, 25, 159-179.

12. Romer, P.M. Endogenous Technological Change. J. Polit. Econ. 1990, 98, 71-102. [CrossRef]

13. Lucas, R.E., Jr. On the mechanics of economic development. J. Monet. Econ. 1988, 22, 3-42. [CrossRef]

14. Bronzini, R.; Piselli, P. Determinants of Long-Run Regional Productivity: The Role of RED, Human Capital and Public Infrastructure; Banca d'Italia: Rome, Italy, 2006.

15. Park, J.S.; Seo, Y.J. The impact of seaports on the regional economies in South Korea: Panel evidence from the augmented Solow model. Transp. Res. Part E Logist. Transp. Rev. 2016, 85, 107-119. [CrossRef]

16. Jouili, T.A. The Role of Seaports in the Process of Economic Growth. Dev. Ctry. Stud. 2016, 6, 64-69.

17. Zhao, Q.; Xu, H.; Wall, R.S.; Stavropoulos, S. Building a bridge between port and city: Improving the urban competitiveness of port cities. J. Transp. Geogr. 2017, 59, 120-133. [CrossRef]

18. Cheung, S.M.S.; Yip, T.L. Port city factors and port production: Analysis of Chinese ports. Transp. J. 2011, 50, 162-175. [CrossRef]

19. Bilbao, O.B.; Rodríguez, P.A. From R\&D to Innovation and Economic Growth in the EU. Growth Chang. 2004, 35, 434-455.

20. Crescenzi, R. Innovation and Regional Growth in the Enlarged Europe: The Role of Local Innovative Capabilities, Peripherality and Education. Growth Chang. 2005, 36, 471-507. [CrossRef]

21. Schumpeter, J. Capitalism, Socialism, and Democracy; Harper \& Brothers: New York, NY, USA, 1942.

22. Grossman, G.M.; Helpman, E. Trade, Innovation and Growth. Am. Econ. Rev. 1990, 80, 86-91.

23. Grossman, G.M.; Helpman, E. Innovation and Growth in the Global Economy; The MIT Press: Cambridge, MA, MA, USA, 1991.

24. Aghion, P.; Howitt, P. A Model of Growth Through Creative Destruction. Society 1992, 60, 323-351.

25. Mervar, A. Pregled modela i metoda istraživanja gospodarskog rasta. Privred kretanja i Ekon Polit 1999, 9, $20-61$.

26. Sundać, D.; Škalamera, A.D.; Babić, M. Poslovno okruženje i intelektualni kapital; Ekonomski fakultet Sveučilišta u Rijeci: Rijeka, Croatia, 2016.

27. Schultz, T.W. Investment in Human Capital. Am. Econ. Rev. 1961, 51, 1-17.

28. Becker, G.S. Investment in Human Capital: A Theoretical Analysis. J. Polit. Econ. 1962, 70, 9-49. [CrossRef] 
29. Bleaney, M.; Gemmell, N.; Kneller, R. Testing the endogenous growth model: Public expenditure, taxation, and growth over the long run. Can. J. Econ. 2001, 34, 36-57. [CrossRef]

30. Caselli, F.; Esquivel, G.; Lefort, F. Reopening the Convergence Debate: A New Look at Cross-Country Growth Empirics. J. Econ. Growth 1996, 1, 363-389. [CrossRef]

31. Levine, R.; Loayza, N.; Beck, T. Financial intermediation and growth: Causality and causes. J. Monet. Econ. 2000, 46, 31-77. [CrossRef]

32. Roodman, D. How to do xtabond2: An introduction to difference and system GMM in Stata. Stata J. 2009, 9, 86-136. [CrossRef]

33. Ullah, S.; Akhtar, P.; Zaefarian, G. Dealing with endogeneity bias: The generalized method of moments (GMM) for panel data. Ind. Mark. Manag. 2018, 71, 69-78. [CrossRef]

34. Arellano, M.; Bond, S. Some Tests of Specification for Panel Data: Monte Carlo Evidence and an Application to Employment Equations. Rev. Econ. Stud. 1991, 58, 277-297. [CrossRef]

35. Arellano, M.; Bover, O. Another look at the instrumental variable estimation of error-components models. J. Econom. 1995, 68, 29-51. [CrossRef]

36. Blundell, R.; Bond, S. Initial conditions and moment restrictions in dynamic panel data models. J. Econom. 1998, 87, 115-143. [CrossRef]

37. European Commission (Eurostat). Regional Gross Domestic Product (PPS Per Inhabitant) by NUTS 2 Regions. 2016. Available online: https://ec.europa.eu/eurostat/tgm/table.do?tab=table\&init=1\&language=en\&pcode= tgs00005\&plugin=1 (accessed on 14 May 2018).

38. European Commission (Eurostat). Maritime Transport of Freight by NUTS 2 Regions. 2018. Available online: https://ec.europa.eu/eurostat/tgm/table.do?tab=table\&plugin=1\&language=en\&pcode= tgs00076 (accessed on 14 May 2018).

39. European Commission (Eurostat). Intramural R\&D Expenditure (GERD) by NUTS 2 Regions. 2018. Available online: https://ec.europa.eu/eurostat/tgm/table.do?tab=table\&plugin=1\&language=en\&pcode= tgs00042 (accessed on 14 May 2018).

40. European Commission (Eurostat). Tertiary Educational Attainment, Age Group 25-64 by Sex and NUTS 2 Regions. 2018. Available online: https:/ec.europa.eu/eurostat/tgm/table.do?tab=table\&init=1\&language= en\&pcode $=$ tgs00109\&plugin $=1$ (accessed on 14 May 2018).

41. European Commission (Eurostat). Unemployment Rate by NUTS 2 Regions. 2018. Available online: https://ec.europa.eu/ eurostat/tgm/table.do?tab=table\&init=1\&language=en\&pcode=tgs00010\&plugin=1 (accessed on 14 May 2018).

42. European Commission (Eurostat). Population Change by NUTS 2 Region. 2018. Available online: https: //ec.europa.eu/eurostat/tgm/refreshTableAction.do?tab=table\&plugin=1\&pcode=tgs00099\&language=en (accessed on 15 May 2018).

43. European Commission (Eurostat). Exports of Goods and Services in \% of GDP. 2018. Available online: https://ec. europa.eu/eurostat/tgm/table.do?tab=table\&init=1\&language=en\&pcode=tet00003\&plugin=1 (accessed on 15 May 2018).

44. European Commission (Eurostat). Government Expenditure on Transport. 2018. Available online: https:/ec.europa.eu/eurostat/en/web/products-eurostat-news/-/DDN-20180904-1 (accessed on 15 May 2018).

45. European Commission (Eurostat). Maritime Transport of Freight by NUTS 2 Regions-Map. 2016. Available online: https://ec.europa.eu/eurostat/tgm/mapToolClosed.do?tab=map\&init=1\&plugin=1\& language $=$ en \&pcode $=$ tgs00076\&toolbox=types (accessed on 20 May 2018).

46. Rodríguez, P.A.; Crescenzi, R. Research and development, spillovers, innovation systems and the genesis of regional growth in Europe. Reg. Stud. 2008, 42, 51-67. [CrossRef]

47. Hong, J.; Chu, Z.; Wang, Q. Transport infrastructure and regional economic growth: Evidence from China. Transportation (Amst). 2011, 38, 737-752. [CrossRef]

48. European Commission. Investment in Human Capital-Assessing the Efficiency of Public Spending on Education. 2017. Available online: http://ec.europa.eu/social/main.jsp?catId=1224 (accessed on 23 March 2019).

49. Bonnefond, C. Growth Dynamics and Conditional Convergence among Chinese Provinces: A Panel Data Investigation Using System GMM Estimator. J. Econ. Dev. 2014, 39, 1-25. [CrossRef]

50. Gordon, I.; Martin, R.; Morrison, P.S. (Eds.) Unemployment and spatial labour markets: Strong adjustment and persistent concentration. In Geographies of Labour Market Inequality; Routledge: London, UK, 2001; pp. $55-82$.

51. Song, L.; Geenhuizen, M. Port infrastructure investment and regional economic growth in China: Panel evidence in port regions and provinces. Transp. Policy 2014, 36, 173-183. [CrossRef] 
52. Yoo, S.H. Seaport infrastructure investment and economic growth in Korea. Int. J. Crit. Infrastruct. 2006, 2, 1-9. [CrossRef]

53. Deng, T.; Shao, S.; Yang, L.; Zhang, X. Has the transport-led economic growth effect reached a peak in China? A panel threshold regression approach. Transportation (Amst). 2014, 41, 567-587. [CrossRef]

54. Canning, D.; Pedroni, P. Infrastructure, long-run economic growth and causality tests for cointegrated panels. Manch. MCR Sch. 2008, 76, 504-527. [CrossRef]

55. Devarajan, S.; Swaroop, V.; Zou, H.F. The composition of public expenditure and economic growth. J. Monet. Econ. 1996, 37, 313-344. [CrossRef]

56. Yu, N.; Jong, M.; Storm, S.; Mi, J. Transport Infrastructure, Spatial Clusters and Regional Economic Growth in China. Transp. Rev. 2012, 32, 3-28. [CrossRef]

57. Lovrić, L. Uvod u ekonometriju; Ekonomski fakultet Sveučilišta u Rijeci: Rijeka, Croatia, 2005.

58. Windmeijer, F. A finite sample correction for the variance of linear efficient two-step GMM estimators. J. Econom. 2005, 126, 25-51. [CrossRef]

59. Roodman, D. A Note on the Theme of Too Many Instruments. Oxf. Bull. Econ. Stat. 2009, 71, 135-158. [CrossRef]

60. Mudronja, G. Inovacije i tehnološki napredak u poslovanju morskih luka i njihov utjecaj na gospodarstvo. In MIPRO 2020 43rd International Convention Proceedings, Opatija, Croatia September 28-October 2, 2020; Skala, K., Ed.; Croatian Society for Information, Communication and Electronic Technology-MIPRO: Opatija, Croatia, 2020; pp. 1737-1742.

61. Mudronja, G.; Jugović, A.; Škalamera, A.D. Research and Development and Rconomic Growth: EU Port Regions. Zbornik Radova Ekonomski Fakultet u Rijeka 2019, 37, 587-602.

62. Eurostat. Eurostat Regional Yearbook, 2018 ed.; Publications Office of the European Union: Luxembourg, 2018.

Publisher's Note: MDPI stays neutral with regard to jurisdictional claims in published maps and institutional affiliations. 